\title{
Lessons from the spread of Bus Rapid Transit in Latin America
}

Santiago Mejía-Dugand, Olof Hjelm, Leenard Baas and Ramiro Alberto Ríos

\section{Linköping University Post Print}

\section{Tweet}

N.B.: When citing this work, cite the original article.

Original Publication:

Santiago Mejía-Dugand, Olof Hjelm, Leenard Baas and Ramiro Alberto Ríos, Lessons from the spread of Bus Rapid Transit in Latin America, 2012, Journal of Cleaner Production, (50), $82-90$.

http://dx.doi.org/10.1016/j.jclepro.2012.11.028

Copyright: Elsevier

http://www.elsevier.com/

Postprint available at: Linköping University Electronic Press

http://urn.kb.se/resolve?urn=urn:nbn:se:liu:diva-85513 


\title{
Lessons from the Spread of Bus Rapid Transit in Latin America
}

\author{
Santiago Mejía-Dugand ${ }^{\mathrm{a} *}$, Olof Hjelmª ${ }^{\mathrm{a}}$ Leo Baas ${ }^{\mathrm{a}}$, Ramiro Alberto Ríos ${ }^{\mathrm{b}}$ \\ a Environmental Technology and Management, Department of Management and Engineering, Linköping \\ University. SE-581 83 Linköping, Sweden. \\ ${ }^{\mathrm{b}}$ Institute for Transportation and Development Policy. 1210 18th Street NW $3^{\text {rd }}$ Floor, Washington DC, 20036, \\ USA. \\ * Corresponding author. Tel.: +46 13 285639, Fax: +46 13149403. \\ E-mail addresses: santiago.mejia.dugand@liu.se (S. Mejía-Dugand), olof.hjelm@liu.se (O. Hjelm), \\ leenard.baas@liu.se (L. Baas), ramiro.rios@itdp.org (R.A. Ríos).
}

\begin{abstract}
Technological transitions and governance theories are employed for the analysis of the dissemination behavior of Bus Rapid Transit systems in Latin America. This process presents interesting characteristics and traits that seem to facilitate the overcoming of barriers and act as catalysts for the adoption of innovation. The present study uses a systems perspective to explore the dynamics of Bus Rapid Transit's adoption by different cities in the region and to follow its geographical dissemination, relying on historical data collected on numerous implemented projects.

The resulting analysis provides an insight on the determinants and key points for the concept's expansion, which may be useful for the study of the dissemination of environmental technologies in cities. Contextualized, solid demonstration projects and incremental innovations, it is here argued, facilitated the adoption of new ways and promoted the dissemination of this urban mobility solution within a homogenous group of cities. A description of the Bus Rapid Transit system's approach to barriers that are also found to hinder the dissemination of environmental technologies provides a learning basis for future dissemination strategies.
\end{abstract}

Keywords: Transitions; Innovative urban solutions; Technology spreading; Urban transformation; BRT Systems

\section{Introduction}

Cities are not only places where people live: cities are where people interact with others, feel a connection with others and develop their collective goals (e.g., economic prosperity, social cohesion, and environmental sustainability). The modern discourse on sustainable cities strongly emphasizes the need for shared, participative and inclusive cities. Cities are expected to be places for the practice of democracy and for the construction of social equality and inclusion (Peñalosa, 2011). More recently, the environmental dimension of urban settlements has gained strength and importance as a basis for such links and activities to emerge and develop.

There can be several vehicles for the achievement of collective goals. Political, economic and social mechanisms are among the most commonly used. In addition, a tool that has shown to be effective at supporting these mechanisms is technology. The technological component of cities is more or less self-evident, since it is one of its most attractive features (Gandy, 2005). Nevertheless, more than the technology as such or its availability, it is the way it is used that really makes this component appealing. The use of technology has been found to be related to the betterment of social (e.g. Cerdá et al. 2012), economic (e.g. Donner, 2007), and environmental (e.g. Baas, 2005) problems. Perhaps most 
interestingly, it has shown to be flexible and effective at solving problems for which its application was not intended in the first place.

This has been the case of Bus Rapid Transit (BRT) systems and their successful implementation in Latin America, on which we will focus our analysis. In most cases, the need to solve mobility problems has been the initial intention for implementation of such systems. Implementing venues were to provide affordable, comfortable and reliable transport means while making city services more accessible for everybody, especially for the least favored. In many cases, they succeeded (see e.g. Ardila-Gómez, 2004; Peñalosa, 2011). An additional, positive side-effect of such systems has been the improvement of environmental conditions (e.g. air quality, noise reduction and energy consumption). Even if environmental redress was not the original intention, we claim that technologies that are designed and intended for the betterment of environmental conditions can learn from these experiences, especially since new technologies normally face barriers that make their implementation difficult (Baas, 2005; Greiner and Franza, 2003; Satterfield et al., 2009).

In particular, transportation systems have different implications and require different characteristics for successful operation, depending on the specific context in which they are implemented. Any decision for a transformation process cannot neglect differences in context; that is, merely relying on rational action irrespective of context often results in failure. In the case of Latin America, particular traits and historical features should be considered when developing any social or infrastructure plan. Even after acrimonious struggles for political independence in Latin America, some of its cities continue to present high gentrification patterns and public infrastructure that favors higher-income groups. This is not completely alien to transportation infrastructure (see e.g. Brand and Dávila, 2011).

\subsection{Bus Rapid Transit (BRT): previous studies, contribution and methodology}

BRT, as defined by the Institute for Transportation \& Development Policy (ITDP) (2007:11) is: " $a$ high-quality bus-based transit system that delivers fast, comfortable, and cost-effective urban mobility through the provision of segregated right-of-way infrastructure, rapid and frequent operations, and excellence in marketing and customer service". BRT does not represent transformation as such, but a means to achieve transformation. This means that BRT is connected to a complex set of actors and networks within the social and technical dimensions of the city. Such connections and the interactions involved could be studied from different perspectives. In fact, BRT systems have been approached from an institutional perspective (Lámbarry Vilchis et al., 2011, 2010; Ponnaluri, 2011), a social perspective (Cahill Delmelle and Casas, 2012; Lin and Wu, 2007), an economic perspective (Cervero and Kang, 2011; Hensher and Golob, 2008; Lindau et al. , 2008), an urban planning perspective (Ardila-Gómez, 2004), a technical perspective (Hensher and Golob, 2008; Hidalgo et al., 2012), and an environmental perspective (Nugroho et al., 2010; Wöhrnschimmel et al., 2008).

Several of these authors agree on the fact that the BRT concept is nowadays widely accepted as a viable solution for many cities' mobility problems. Hensher and Golob (2008) compared the performance and infrastructure of 44 operational BRT systems, and various isolated projects have been analyzed from the perspectives described above. Thus, there is a lack of studies analyzing the connection among the implementing venues, the transmission of ideas from one to the other, and the impact that incremental improvements have had on the geographical expansion of the concept. We therefore find it important to offer an analysis of the dissemination dynamics of the concept in search of characteristics and explanations for such acceptance. Information from numerous implemented 
projects is analyzed with a focus on the initial stages of the dissemination process (i.e. projects in Latin America). Supported by technological transitions and governance theories, we identify and analyze the characteristics that offer an explanation to the concept's dissemination behavior, seeking for traits that could be reproducible for the implementation of environmental technologies. The aim of this article is therefore to describe the dissemination dynamics of the BRT concept in Latin America and to identify and analyze the determinants of this behavior. This is done with the intention to provide foundations for learning about the dissemination and implementation process for other technology concepts.

With this aim in mind, this article seeks to answer the following research questions:

- Are there any key points in the development path of BRT systems in Latin America that stimulated their dissemination in the region?

- What traits have been and could be further replicated to facilitate the spreading of other type of technology concepts?

We collected information from the 30 Latin American cities that had implemented BRT systems by 2011. Such information included the name of the system, its opening date, the total length of the main lanes (trunk), number of passengers transported, peak throughput, number of stations, and number of buses. The data were gathered using the ITDP database. Other sources of information were BRT operators and local authorities in different cities, collected through interviews and personal communication. ITDP data were classified and filtered to construct a chronological map illustrating how the BRT concept was replicated and the dissemination pattern that it has presented since its first years. In addition, tables and figures were constructed to illustrate the speed with which the concept spread and the particular traits that marked important milestones for its successful implementation in Latin America. Visits to some BRT systems - Guadalajara (Mexico), Mexico City (Mexico), Bogotá (Colombia), Johannesburg (South Africa), Guangzhou (China), Cartagena (Colombia), Buenos Aires (Argentina), and Santiago (Chile) - contributed to a better understanding of the BRT system's functioning and approach to different barriers.

Socio-technical transitions and governance theories were considered for the description and understanding of how the BRT system managed to align and coexist with the existing socio-technical regime in the different cities. Such theories are appropriate for the analysis of sustainable urban transformation since they provide the tools for the identification and classification of the different phases and the paths to solutions taken by different cities to improve urban conditions. By using an analysis of BRT systems in Latin America, we describe how this innovative mobility solution evolved and spread. We examine the possibility of using the system's path and development behavior to study similar contexts, sectors, or technologies. Section 2 discusses theoretical approaches to innovations and the requirements for such innovations to enter and successfully adjust to the conditions of the urban sphere. Section 3 describes the propagation and implementation process of BRT systems throughout Latin America. Section 4 presents a discussion about the traits and characteristics that make the BRT case interesting and analyses how its success can be explained from the theoretical perspectives exhibited in section 2. Section 5 states the conclusions. 


\section{Transition and dissemination: transforming socio-technical regimes.}

An analysis of BRT as an isolated technology is counterproductive when seeking to expand the scope to the urban level. The manifold interactions between this concept and the system context in which it is embedded demand a systemic approach. In this regard, the multi-level perspective (MLP) offers a plausible framework for the understanding of the dynamics of technological transitions and sociotechnical systems. In particular, it will help us comprehend how incremental innovations built up from previous experiences and allowed this mobility solution to adapt and propagate geographically in Latin America.

MLP describes three different levels of structuration of activities in the local practice. Such structuration will define the complexity of the social networks that interact within each level and thus the difficulty to influence them (Geels and Schot, 2010). The socio-technical landscape (macro-level) has been addressed by e.g. Ardila-Gómez (2004), who analyzed large changes over long periods of time that opened the windows of opportunity for BRT novelties to step into the meso-level. Our interest lies in what are defined as socio-technical regime (meso-level) and niches (micro-level). At the micro-level, there are numerous innovation activities happening under a very dynamic environment, although in isolated and experimental manners. Innovations constantly emerge, but face difficulties when - and if - they manage to step into the meso-level and have to interact with the existing regime. At this level, changes take more time and occur in an incremental way and cannot be forced since this could create strong barriers and generate opposition from stakeholders (Perrels, 2008). In the case of BRT, once windows of opportunity opened (e.g. good financial situation, political support from higher government levels, etc.), innovations from the micro-level encountered a chance to step in and enrich practices that were already embedded in the meso-level.

Actors at the micro-level hope for radical changes that modify or replace the existing regimes embedded in society due to economic or technological lock-ins (see e.g. Baas, 2005; Geels, 2002). It is disturbances occurring at the meso-level that provide the opportunity for innovations from the niche level to step into the socio-technical regime (Geels, 2005, 2002). However, although on a smaller scale, such innovations bring with them disturbances, due to the fact that they are new and unknown. To a large extent, the magnitude of this disturbance will define the ability of an innovation to align with other connected subsystems of the regime, since these subsystems are protected from excessive disturbance by suspiciousness and distrust (Rogers et al., 2005).

Such barriers can be analyzed and understood through governance mechanisms. The urban sustainability debate requires the inclusion of the governance dilemma, given the public (shared) nature of the environment and the conditions under which sustainable innovations compete (Hillman et al., 2011, Smith et al., 2005). Hillman et al. (2011) claim that changes aiming at sustainability rely on social initiatives and governance happening outside traditional policy instruments and take the shape of a bottom-up approach. By fostering participation, experimentation, and collective learning, power is strengthened, which in turn facilitates agency (Smith et al., 2005). How this power is actually used and exploited is of our particular interest when describing urban transformations. Local actors and a network of similar context-bounded knowledge can nurture the spreading of sustainable innovation. By considering the importance of vernacular knowledge and local needs, bottom-up approaches have frequently shown to be stronger and better at facilitating the understanding of any solution's applicability to specific conditions (WBGU, 2011). In this respect, Rogers (2003) mentions that innovations that are compatible with existing values and are easy to comprehend and adapt are adopted more rapidly. In addition, culturally compatible groups facilitate the interaction and the 
strengthening of the social networks needed for the innovation to propagate, since less energy is needed for the transmission of information (Rogers et al., 2005).

Hillman et al. (2011) describe the cognitive (how a problem is perceived and how networks are built to deal with the problem) and the normative (how a common goal and concept of "what is good" is formed) mechanisms. These two mechanisms are useful for our approach because they refer to the important role that contextualization plays when innovations are transmitted, adopted, or replicated (and successfully implemented). Given the complex interactions among the components of sociotechnical systems, the concept of sustainability could be context-dependent (Geels, 2002; Grin et al., 2010). Many times, developmentalist characterizations have put aside the role of vernacular knowledge, considered by some as not urban and not modern, or standing in the way of development (Robinson, 2011). As it will be discussed below, the categorization of countries and their cities according to their comparative level of development has hindered the possibility of learning between contexts (McFarlane, 2006). However, current social, political and economic trends have proved the usefulness of such interactions. According to Jaime Lerner (former mayor of Curitiba, Brazil), it was not until he and his team knocked on Volvo's door in the 1990s endowed with technical and economic feasibility studies, that this company started paying serious attention to the potential market of mass transport in cities (Pereira, 2003). A decade later, Volvo's former president Leif Johansson would say during a conference in Gothenburg: "We refuse to sell the old technology of the West to the developing world. We are beginning to see demand for skill jumping in the developing world. There is no demand for old systems." (Heller, 2002:1). As we will discuss later, the attention devoted to adaptive solutions can dethrone the paradigmatic idea of sustainable cities. Such solutions must show the ability to respond to the environment and to align to the cities' complex dynamics. The consideration of actors, rules, and technology as equal parts of the equation can widen the narrow conceptions of standardized solutions (Konrad et al., 2008).

\subsection{Moving forward - Shaping cities from the bottom-up}

Portugali (2000) explains that the concept of city can diffuse and move through space and time and experience abrupt periods of change and revolution. Particular interpretations can emerge during each epoch, where ideal types circle around a prototype; McFarlane (2010) calls these "the usual suspects." In fact, such interpretations have led to categorization and developmentalism (as mentioned above). Developmentalism describes cities as 'developed', 'developing' or 'underdeveloped' (McFarlane 2010), or 'mature', 'transitional' or 'emerging' (Gareth Lofthouse, Economist Intelligence Unit, 2004).

Technology (or its availability and the intensity of its use), among other things, has become a common comparable feature due to the role it has achieved within the urban sphere. Effective solutions (not necessarily technical solutions) have existed for a long time in different places around the world. However, as Peñalosa (2011) mentions, it is common that only when globally attractive cities (i.e. 'the usual suspects') implement a given solution that "the rest" of the cities pay attention. Urban studies have generally neglected the experiences and knowledge that cities outside that preferential group can contribute to urban theory, since the reference is often made to Western European or North American cities (McFarlane, 2010). Nevertheless, today's sustainability challenges and urban dynamics claim for cities to look for solutions that adapt to local conditions and that are compatible with budgets and indigenous systems. Uncertainty about new systems can be overcome when innovations and their 
potential benefits are observable and tangible, which in turn facilitates feedback and diffusion (Rogers et al., 2005). For instance, in his study about Curitiba and Bogotá, Ardila-Gómez (2004) found that planners and politicians were not only looking at similar (i.e. "less attractive”) cities, but getting feedback and valuing the experience of local stakeholders, those who would actually operate any proposed solution.

Urban sustainability can be achieved by asking whose visions should construct the cities we want to live in; which social interests and what expectations produce such visions (Hodson and Marvin, 2010) and whether the vehicles for achieving them are to be found in prototypes or are to be customized and shaped by local conditions and local stakeholders. The apparent discontent with the present way cities are organized has triggered optimistic, futuristic visions of what cities should become. Some critics have argued that some of these visions have been driven by authoritarian ideals and have even been related to totalitarianism (Pinder, 2002), which is particularly important for our analytical approach to urban sustainability. Unrealistic images of the city can create un-sustainability if the right stakeholders are not considered in such views. Sargisson (2011) proposed Dubai as an example of a modern, yet unsustainable city "driven by values and power structures that are antithetical to a green future." On the other hand, cities such as Mexico City, once mentioned as the "anteroom to an ecological Hiroshima" (Toufexis, 1989), have shown a clear recovery in different areas (e.g., air pollution control and environmental governance) (Economist Intelligence Unit, 2010). Both problems and improvements can be, at least partially, attributed to technology. However, in this regard Geels and Schot (2010: 45) note: "It is the combination of humans and non humans that create functional configurations that work."

\section{The Study Object: BRT Systems}

The idea of what is today categorized as a BRT could be tracked to the 1930s in the United States. In Latin America, Lima (Peru) has been considered an initiator of these kinds of systems with its Vía Expresa, which began operating in 1972. The system as such is not considered a BRT, but it undoubtedly laid the ground for prioritized public transport in the region. Not long after Lima, Curitiba (Brazil) opened the Rede Integrada de Transporte system, improving aesthetics, collection, coverage, and operation. The city is commonly accredited as the forerunner of the modern BRT systems (ITDP, 2011).

BRT's characteristics vary depending on the particular conditions of the city where it is implemented. Nevertheless, a fundamental feature is to have segregated bus ways over the majority of the length of the system's trunk. Additionally, it must comply with at least two of the following features (ITDP, 2007): an integrated network; enhanced, secure, and comfortable stations; level access between the platforms and the buses; proper location of stations on the roadway; pre-boarding collection and fare integration between routes; restricted entry to the system to prescribed operators; distinctive marketing features; low-emission vehicle technologies; centralized control center with location and management technologies; special provisions for physically-disadvantaged groups; and clear route maps and time information.

Most of these features do not seem to be very innovative when compared with similar systems operating in many cities of the Northern Hemisphere. However, one must understand the way in which transportation systems evolved organically in most Latin American cities to understand the scope of the transformation that BRT systems achieved: individual and private companies had gained control 
over the cities' transport service to the general public. This fact presents a set of problems due to the lack of order and the difficulties for control. Some of these problems are: lack of security, uncoordinated operation, bad equipment maintenance, high greenhouse gas and conventional pollutants emissions (low quality of the fuels used), and the subsequent bad reputation of public transport. Additionally, it is difficult for transit authorities to coordinate such a large amount of buses running throughout the city without an apparent set of well-defined, physical boundaries and clearly established rules. Controlling (i.e., stopping, fining, and chastising) one bus not only implies disrupting the operation of the bus as such and of the vehicles around it, but also disrupting the mobility of the buses' passengers. Pioneers and advocates of BRT systems highlight the provision of efficient mobility for people, not vehicles.

To analyze the BRT systems' growth, we will focus on Latin American cities, where the concept of BRT originated and gained strength after being dormant for several decades. New projects in Latin America, in particular the projects in Curitiba (Brazil) and Bogotá (Colombia), contributed the most to the current maturity of the concept. According to ITDP (2007), these two cities' BRTs proved to be compatible with the cities' planning as well as their budget constraints. We will show this in more detail in the following section. Examples of cities inspired by the system's positive direct and indirect impacts, demonstrated in large scale (e.g. Bogotá with its more than seven million inhabitants) are: Cartagena, Bucaramanga and Pereira in Colombia; Guatemala City in Guatemala; Mérida in Venezuela; São Paulo and Porto Alegre in Brazil; Buenos Aires in Argentina; Guadalajara, Mexico City and León in Mexico; Quito and Guayaquil in Ecuador; Lima in Peru; and Santiago in Chile.

\subsection{The Spread of the BRT System}

The spread of the BRT systems has been a matter of non-hierarchical connections, where each element (city) is affected/influenced and at the same time each element affects/influences any other element. The opposite would be a rigid, subordinated array where elements unavoidably inherit the features of those elements standing on a higher level on the hierarchy (e.g., "the usual suspects"), with little or no degrees of freedom. As we stated above, solutions that might be incompatible with local conditions and realities are destined to fail or create an endless loop of problems and ineffective solutions (e.g., some imported technologies). Expensive solutions planned exclusively or to a large degree by external actors are rarely implemented in these cities, and if they are, may provoke suspicion as they could involve sinecures or divert attention from other priorities. Buying magic-bullet solutions leaves less time and money for cities to focus on fixing the basics (Katz and Altman, 2007). The extent to which solutions work is a function of the availability of resources and the way they are coordinated (Smith et al., 2005).

Latin American cities share experiences and knowledge and create connections, particularly regarding mobility issues, as we will discuss later. These links promote learning and the search for improvement of already proven solutions: "Cities can learn from each other and history. [...] stakeholders can [...] benefit from the experiences - both good and bad - of other cities and apply this learning to their own situation" (WBCSD, 2009:4). The spread of the BRT concept can be depicted in three different waves (Figure 1). From the data obtained, it is difficult to define which city influenced the decision of which others to implement the system. However, the different stages are shown chronologically in reference to what we consider as important milestones for the concept's dissemination (more detail can be found in Figure 2). 


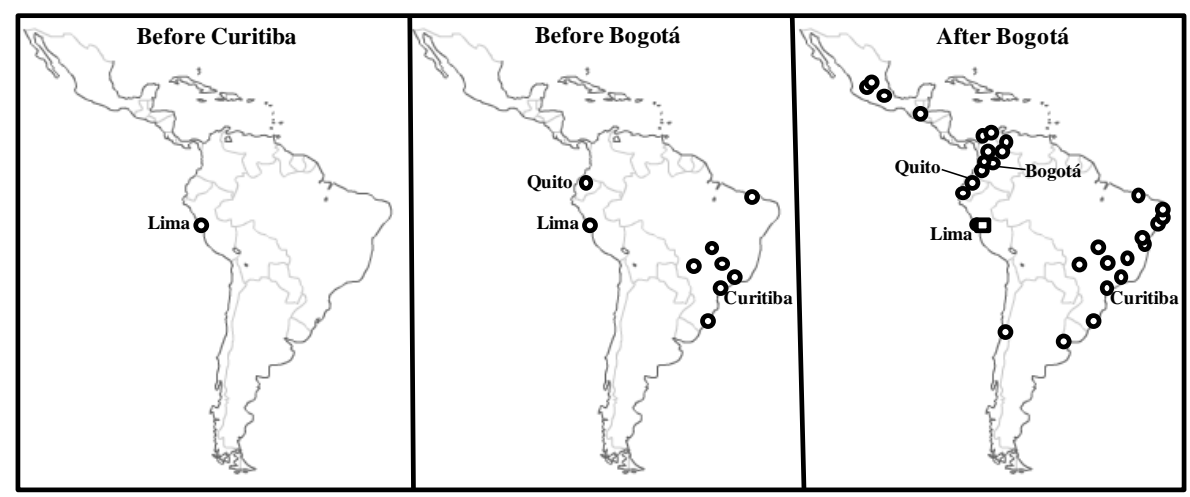

Fig. 1: Operational BRT projects in Latin America as of 2011. Important milestones for the concept's dissemination are shown in three different waves. Lima has two markers, representing both its condition as a pioneer of prioritized public transport and its implementation of BRT in 2010.

Only operational projects are depicted in Figure 1. However, it is important to mention that the construction of three new BRTs - Monterrey and Querétaro in Mexico and Rio de Janeiro in Brazil and the expansion of four existent BRTs - Cartagena (Colombia); Mexico City (Mexico); and Belo Horizonte and Curitiba (Brazil) - are planned to start in 2012. Brazil has announced the construction of around $500 \mathrm{~km}$ of BRT lanes in twelve cities (partly in response to the upcoming World Cup in 2014 and the Olympic Games in 2016) (Embarq, 2011), while the Mexican government announced in 2010 their support of 20 BRT projects in the most populated cities in the country (FONADIN, 2010).

The four cities highlighted in Figure 1 are also shown in Figures 2a and 2b. Graphically, these points can be seen to have an influence on the slope. Empirically, these cities gave the momentum to the whole system's expansion throughout the region. In Figure 2a, one has to bear in mind that the segments between two projects represent the construction of the system, while the points represent the inauguration year. Rogers et al. (2005:12) describe in a more general manner this behavior, showing the complete set of phases for the diffusion of innovations (cumulative normal distribution and normal distribution, respectively). The process starts with a low level of adoption, which is followed by a second stage where uncertainty and distrust are overcome and changes adopted widely, and stabilizing in a final stage when it is difficult to continue changing the system.

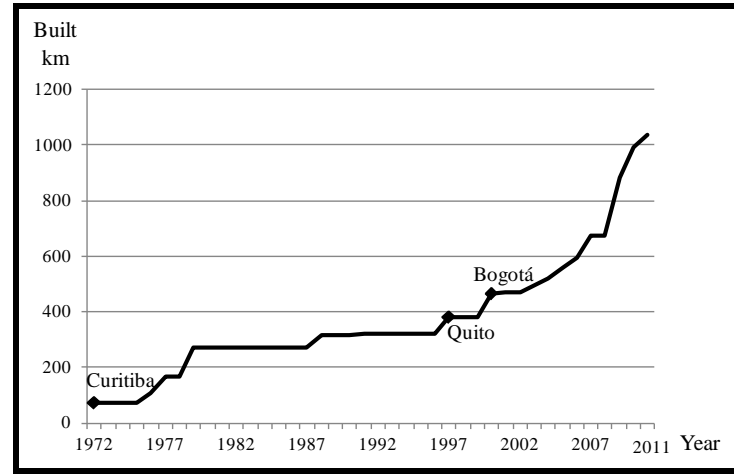

Figure 2a: Cumulative built $\mathrm{km}$ of BRT in Latin America (1972-2011).



Figure 2b: Number of Latin American cities implementing BRT (1972-2011). 
The figure shows the apparent impact that projects such as the ones in Curitiba and Bogotá had on spreading the concept when the cumulative number of kilometers of BRT constructed is compared over time. Incremental improvements added to the original concepts and the experience gained by these solid demonstration projects seem to have had a major influence on the decision-making process and their adoption by other cities:

- Lima (Peru): The city pioneered these types of systems in Latin America with its Vía Expresa and the concept of segregated lanes.

- Curitiba (Brazil): This city improved dramatically the system's appearance regarding stations, the collection system, and the coverage. The city also successfully connected the planning of new areas to the system.

- Quito (Ecuador): Quito was the first city outside Brazil to implement BRT systems in Latin America.

- Bogotá (Colombia): After almost three decades of slow developments, Bogotá successfully implemented the system in a short time. The improvements made to Curitiba's model (e.g., overtaking improvements, routes flexibility, frequency, and the collection system) boosted the implementation in the region.

Politicians and urban planners in Curitiba visited the Peruvian system (Ardila-Gómez, 2004), adopted and improved its characteristics, and implemented a system in their city based on its basic idea (segregated lanes). The Rede Integrada de Transporte in Curitiba aligned with the population's demand for public transport and developed some of the most successful characteristics of modern BRTs, although it did not attract important international attention at the beginning. Quito was attracted by the concept. However, it was Transmilenio in Bogotá that gained international recognition and gave momentum to the replication of BRT, contributing to the maturity of the concept with innovative ideas that provided more flexibility to the network, extended the coverage, and improved the conditions of connected sub-systems (bicycle paths and pedestrian facilities). Politicians and urban planners adopted the best characteristics from the most successful and representative projects and developed them further. Latin American cities seem to have created a network that facilitated the propagation of innovative solutions that shared a common view, while focusing on their own resources (Hodson and Marvin, 2010, 2009). The network has grown stronger because cities have not only become recipients of these solutions, but also have become the contexts for the enhancement of such innovations, given their territorial governance priorities and the degree of control that is required (Hodson and Marvin, 2010). In Latin America, between 1972 and 1997, BRT systems were only implemented in Brazilian cities, following the model from Curitiba.

Although the article focuses on Latin America, a global perspective helps to illustrate this trend, strengthened by the influence of Chinese and Indian cities (Figures 3a and 3b). This can be a reflection of the high urbanization rates that China and India are experiencing, a process more or less stabilized in Latin American cities (after having the same trend during the second half of the $20^{\text {th }}$ century). A similar trend was shown by Hidalgo et al. (2010). 


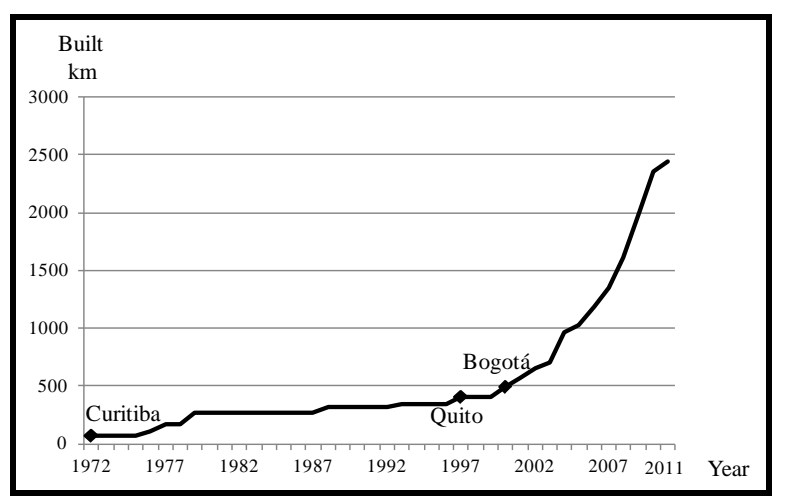

Figure 3a: Cumulative built $\mathrm{km}$ of BRT, globally (1972-2011).

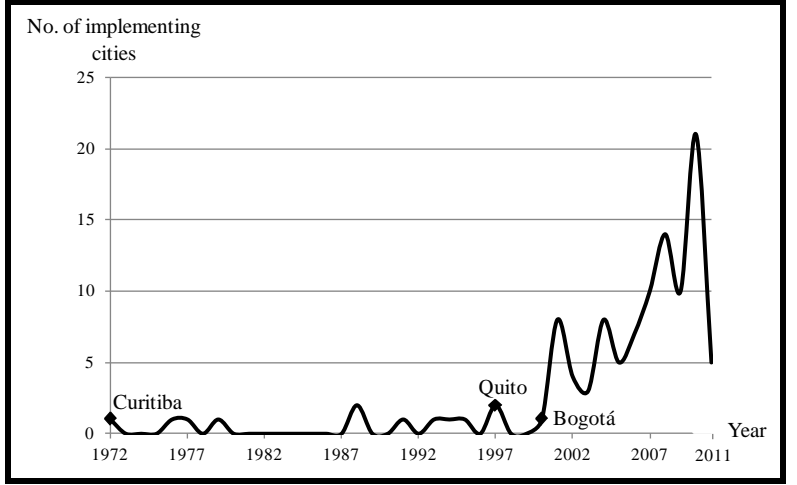

Figure 3b: Number of cities implementing BRT, globally (1972-2011)

\section{Analysis and Discussion}

The dynamics of innovations were discussed in section 2.1 with the help of the MLP model. It was shown that when new concepts are introduced in a socio-technical regime, they usually face obstacles. Innovative solutions face several difficulties breaking through the existing regime: political (regulations), socio-cultural (user practices), technical (infrastructure, maintenance networks), and economic (financing, maintenance) (Geels, 2002). The incompatibility of imported solutions with the local conditions can mean failure for many of these concepts (Rogers et al., 2005). Sometimes, this failure can leave a technological dependence that will not be appreciated by all stakeholders. As we discussed, knowledge and information is more easily transmitted among stakeholders when innovations cause less disruptions and disturbance to other sub-systems. Change agents - be it politicians, planners or technology suppliers - might fail when background information is not considered and when the suggested innovation does not align to e.g. existing infrastructure or socially accepted practices.

Having this in mind, innovations can be classified in a simple two-dimensional model. Figure 4 is built considering how different innovations and their characteristics influence the social, economic, and environmental spheres. This model is based on the normative (the impact society desires) and the cognitive (how the agreed-upon solution disrupts the existing regime and the connected sub-systems) mechanisms mentioned in section 3 . The degree to which a solution aligns to the existing regime is represented in the vertical axis. A higher degree of alignment refers to the capacity of the introduced solution to operate without major disruptions to the system and sub-systems connected to it. The horizontal axis describes the positive impact directly associated to the new solution. 


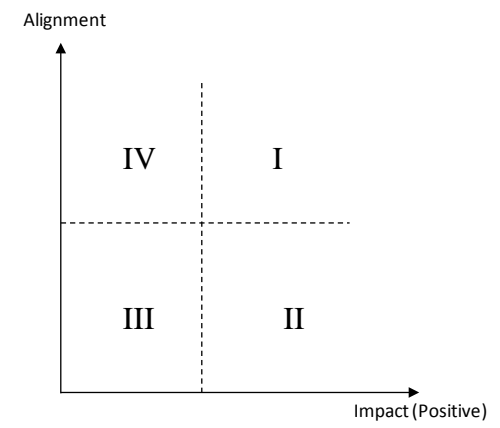

Fig. 4: Classification of urban innovations according to their impact on the existing regimes and their ability to align with current systems at the meso-level.

With respect to urban mobility improvements, the above figure can be interpreted as follows:

- Quadrant I: The solution presents compatibility with existing systems, mainly because it requires a minor change in mindset and technology. There is a large positive impact on the social (e.g., improvement of living conditions, and accessibility to the city's services), the environmental (e.g., lower emissions, and low impact attributed to the civil-construction activities), and the economic spheres (e.g., low comparative costs, and increased productivity). Best practices that could be classified within this quadrant are BRT systems, cable cars, and well-planned improvements for non-motorized transport (NMT) (cycling and pedestrian facilities).

- Quadrant II: Incompatibility with existing sub-systems, dramatic infrastructural changes, and/or a difficult (traumatic) adoption of the new ways. In the long-term, however, there could be a large positive impact on the social, environmental, and economic spheres. These solutions represent very high costs and a long return-on-the-investment time (thus unreachable for many cities in the developing world) and could necessitate subsidies. Concrete examples are some subway projects, and some heavy-rail and light-rail transport systems.

- Quadrant III: Incompatibility, low social benefits, high environmental impacts, and high costs. A good example is an elevated highway that is accessible only for those who can afford to pay the toll. Other examples are initiatives to increase capacity for cars (broadening roads and subsidizing fuels) whose externalities are not necessarily reflected via prices.

- Quadrant IV: Compatibility and low costs. A low positive social and environmental impact related to the solution. Good examples are poorly designed bicycle paths that are not integrated with the rest of the transport network, unsafe and discontinued bicycle routes and some ineffective light-BRTs that feature no physical segregation from mixed traffic.

Which quadrant is best depends on each particular case, on societal values and accessibility to resources. There could be an inclination towards Quadrant I and Quadrant II given their positive impacts. Although there is a significant difference in the economic sphere, positive environmental and social impacts from solutions within Quadrant II could offset such conditions in the long-term. However, the capital-intensive nature of solutions in Quadrant II represents a hindrance for many cities in the low-income group. 
Lack of financial resources is not the only barrier hindering the implementation and dissemination of environmental technologies. Several studies have identified this and other barriers (e.g. Baas, 2005; Greiner and Franza, 2003; Jaffe et al., 2005; Mejía-Dugand et al., 2011b; Mondal et al., 2010; Satterfield et al., 2009). Furthermore, several authors have specifically focused on barriers for environmental technologies and practices with a focus on the transport sector (e.g. Black, 2000; Byrne and Polonsky, 2001; Low et al., 2010; Steenberghen and López, 2008; Wiedmann et al., 2011). From all the above authors, barriers can be summarized into: $i$ ) regulatory, ii) organizational, iii) financial, iv) political, v) cultural, vi) technical, and vii) conceptual barriers.

Keeping in mind the model in Figure 4 and considering information gathered during different meetings with stakeholders belonging to government, academia, and non-governmental organizations in different cities, Table 1 lists and classifies barriers to the implementation of many urban mobility solutions normally presented to decision makers. In addition, it describes the possible reasons for the successful adoption of the BRT concept. It is very important to mention that there were other barriers and difficulties that had to be overcome too, but they are considered to be characteristic of each city's political and social situation. For example, all the negotiations that needed to be undertaken with bus operators regarding demand and mechanisms for determining the fare in Curitiba and Bogotá, were a direct cause of the specific way in which the transport sector developed in the past in these cities (for more detail, see Ardila-Gómez, 2004). However, as we stated above, our interest is to find traits that could be common to most cities and to most environmental technologies.

Table 1. Classification of barriers faced by new technologies/concepts at the meso-level and the BRT's approach.

\begin{tabular}{|c|c|c|}
\hline Barrier & Type & BRT approach to overcome barrier \\
\hline $\begin{array}{l}\text { Long-term } \\
\text { commitments and } \\
\text { subsidies (Black, 2000; } \\
\text { Mondal et al., 2010; } \\
\text { Steenberghen and } \\
\text { López, 2008). }\end{array}$ & Financial/Political & $\begin{array}{l}\text { - Profitable and operational without subsidies and in a } \\
\text { comparatively shorter time }\end{array}$ \\
\hline $\begin{array}{l}\text { Capital intensiveness } \\
\text { (Black, 2000; Mondal } \\
\text { et al., 2010; Satterfield } \\
\text { et al., 2009; } \\
\text { Steenberghen and } \\
\text { López, 2008) }\end{array}$ & Financial & $\begin{array}{l}\text { - Comparatively cheaper than other mobility solutions } \\
\text { - Because it uses part of the existing infrastructure, its } \\
\text { construction generates less disruptions }\end{array}$ \\
\hline $\begin{array}{l}\text { Change of technology } \\
\text { and mindset (Black, } \\
\text { 2000; Greiner and } \\
\text { Franza, 2003) }\end{array}$ & Cultural/Technical/Conceptual & $\begin{array}{l}\text { - Low resistance because of its aligning ability and } \\
\text { well-known technology (internal combustion engines) } \\
\text { - Education in stations and media about the new } \\
\text { collection system }\end{array}$ \\
\hline $\begin{array}{l}\text { Foreign dependence } \\
\text { (Steenberghen and } \\
\text { López, 2008; } \\
\text { Wiedmann et al., 2011) }\end{array}$ & Financial/Cultural/Technical & $\begin{array}{l}\text { - Most of its technology, operation and maintenance } \\
\text { requirements are well-known. This means that lead } \\
\text { times and costs can be reduced by using local } \\
\text { companies }\end{array}$ \\
\hline $\begin{array}{l}\text { The solution's } \\
\text { reputation (Black, 2000; } \\
\text { Greiner and Franza, }\end{array}$ & Cultural/Organizational & $\begin{array}{l}\text { - One single company/image instead of several } \\
\text { competing companies } \\
\text { - Paying operators per kilometer logged, not per }\end{array}$ \\
\hline
\end{tabular}




\begin{tabular}{|l|l|l|}
\hline 2003) & & $\begin{array}{l}\text { passenger served } \\
\text { - New vehicles and stations } \\
\text { - Education of drivers } \\
\text { - Restricted interaction with passengers and other } \\
\text { drivers }\end{array}$ \\
\hline $\begin{array}{l}\text { Competition with other } \\
\text { systems/solutions (Low } \\
\text { et al., 2010) }\end{array}$ & $\begin{array}{l}\text { Cultural/Financial/ } \\
\text { Technical }\end{array}$ & $\begin{array}{l}\text { - Integration with the rest of the transportation network } \\
\text { - Feeding routes from small or distant neighborhoods } \\
\text { - Non-motorized transport was given space and } \\
\text { connected to stations }\end{array}$ \\
\hline $\begin{array}{l}\text { Uncertainty about the } \\
\text { solution's effectiveness } \\
\text { (Greiner and Franza, } \\
\text { 2003; Wiedmann et al., } \\
\text { 2011) }\end{array}$ & Cultural/Technical & $\begin{array}{l}\text { - Bus traffic was widely accepted and used } \\
\text { - New features like the payment system represented a }\end{array}$ \\
\hline $\begin{array}{l}\text { Rigidity and } \\
\text { technological lock-in } \\
\text { (Jaffe et al., 2005) }\end{array}$ & Cultural/Technical & $\begin{array}{l}\text { - Flexibility of the segregated lanes in the surface } \\
\text { - Possibility of adapting the new space for vehicles } \\
\text { using a different energy source or motion system }\end{array}$ \\
\hline
\end{tabular}

Such an approach has shown to be effective and adaptive to the context of most Latin American cities where the concept has been considered. The successful propagation of the idea can be described in terms of the applicability of the concept under similar conditions, its flexibility to address those features that may vary from city to city, and the ease with which it can be transmitted, copied, or adopted. Several important factors are highlighted below:

- Leadership and political influence: charismatic and visionary mayors (e.g., Lerner in Curitiba and Peñalosa in Bogotá) managed to promote and complete the first phases of the project in a relatively short time (Ardila-Gómez, 2004; ITDP, 2007). As a contrasting example, the construction of a metro in Bogotá has been discussed since 1950 without success (Portafolio, 2011). Political will, however, cannot be attributed to the BRT system as such, but to societies' and their leaders’ own characteristics.

- Lower costs: BRT represents a cheaper option compared to a metro or a light train, in a scale of up to1:10 and 1:4, respectively (ITDP, 2007). This is mainly due to the use of existing infrastructure.

- Organized and centralized control: Fatalities and insecurity decreased since there is no competition for passengers among the different operators (Ardila-Gómez, 2004).

- The reputation of the new system: By creating a single brand with great focus on marketing and new vehicles, establishing a pre-boarding collection system and physically separating buses from mixed traffic, BRT systems succeeded in improving public transport's reputation (ITDP, 2007), partly affected by the wrong structural and economic incentives (ArdilaGómez, 2004). 
When analyzing the dissemination of the concept, it can be seen that the first phase (i.e. the segment Curitiba - Quito in Figures 2a and 2b) corresponds to what Rogers et al. (2005) call the "early stage". As mentioned above, although the system implemented in Curitiba presented palpable benefits, only cities with very close cultural ties, i.e. Brazilian cities, decided to follow. Quito can be seen as a risktaker, although very much "protected" by the experiences accumulated during 25 years by its predecessors, and the - by then - recent improvements that Curitiba had again contributed with. Three years later Bogotá implemented the system, which can be interpreted (from figures 2a and 2b) as the initial point of the stage that Rogers et al. (2005) call "cascades of change". At this point, the slope changes in both figures, which is a sign of the overcoming of uncertainty and distrust, and the ease with which the concept is transmitted from there on can be seen in the rapid increase of adopting cities in Figure 2b. The model proposed by Rogers et al. (2005) predicts a new inflection point and a subsequent third stage, in which the stability of the first stage is reached again. When this point will be reached is difficult to say, but as mentioned in section 3.1, there are more planned projects for the upcoming years in Latin America, so more growth can be expected, at least in the short term. From a global perspective, although the Americas, Europe, Asia and Oceania have implemented numerous projects, the African continent, which is urbanizing rapidly, has so far implemented just a few.

\section{Conclusions}

This article asked two questions: Are there any key points that stimulated the dissemination of BRT systems in Latin America? And what traits could be reproduced by other type of technology concepts? With the data collected from numerous BRT projects implemented in different cities across Latin America, it was possible to describe the dissemination process from 1972 - when it was first implemented in the region - until 2011. Together with background information about the history of the development of such systems, a graphical analysis permitted the identification of important key points (cities) that seem to have influenced this process. In particular, two stages were identified based on Rogers et al.'s (2005) model: the "early stage” and the "cascades of change” stage. The key points contributing to the overcoming of the distrust and uncertainty that are inherent to the acceptance of innovations where found to be the cities of Lima (Peru), Curitiba (Brazil), Quito (Ecuador) and Bogotá (Colombia). These cities contributed incremental improvements to the concept that proved to be adaptive to other cities sharing similar conditions and acted as contexts for the application of new ideas and the strengthening of the basic ones. Strong demonstration projects and the involvement of local stakeholders demonstrated tangible benefits and advantages over other systems that might create larger disturbances on the existing regimes or that are incompatible with cultural practices or indigenous systems. Such conditions facilitated the adoption by more cities in the region, especially after its implementation in Bogotá, a city with more than seven million inhabitants.

Various barriers to the implementation of environmental technologies identified by literature were listed and categorized. The approach of the BRT concept to these barriers was described based on field visits and experiences from different stakeholders. Learning from the dissemination process of the BRT concept is suggested as useful for the design of strategies for the implementation of environmental technologies. The need for strong demonstration projects is an outstanding trait in the analyzed case, but the underlying reason behind it, i.e. the need for context-bounded and adaptive solutions, has to be taken seriously, based on the facts presented here. By learning from other cities in similar contexts (culturally, socially and politically), implementing cities might feel backed by an existing network of more experienced cities; technically, politically, socially and emotionally. Any 
opportunity to innovate locally will be appreciated by cities, considering the fact that they are looking to attract regional and international visibility. Regarding sustainability and urban transformations, the great accomplishment of any solution would be a radical change in scope. In this case, the change in scope can be considered radical not only in the improvements in mobility and the environmental benefits, but also in the role that public transportation has achieved over private transportation, the adoption of the new ways, and the acceptance and spread of the idea throughout different cities in Latin America. All this has happened over a comparatively short period.

\section{Acknowledgement}

We are grateful to the Swedish Governmental Agency for Innovation Systems (VINNOVA), which financed this study. Earlier versions of the article benefited from discussions with Björn Wallsten, Wisdom Kanda and Paul Fenton and from comments by two anonymous reviewers. We also thank The Swedish International Network for Exchange \& Commerce (SINEC) and The Swedish Trade Council in Mexico for their valuable contributions.

\section{References}

Ardila-Gómez, A., 2004. Transit planning in Curitiba and Bogotá. Roles in interaction, risk and change. Ph.D. Thesis, Massachusetts Institute of Technology.

Baas, L.W., 2005. Cleaner production and industrial ecology. Dynamic aspects of the introduction and dissemination of new concepts in industrial practice. Eburon Academic Publishers, Delft.

Black, W.R., 2000. Socio-economic barriers to sustainable transport. Journal of Transport Geography 8, 141-147.

Brand, P., Dávila, J. D., 2011. Mobility innovation at the urban margins - Medellín’s Metrocables. City: analysis of urban trends, culture, theory, policy, action 15(6), 647-661.

Byrne, M.R., Polonsky, M.J., 2001. Impediments to consumer adoption of sustainable transportation: Alternative fuel vehicles. International Journal of Operations \& Production Management 21(12), 1521-1538.

Cahill Delmelle, E. and Casas, I., 2012. Evaluating the spatial equity of bus rapid transit-based accessibility patterns in a developing country: The case of Cali, Colombia. Transport Policy 20, 36-46.

Cerdá, M. et al., 2012. Reducing violence by transforming neighborhoods: A natural experiment in Medellín, Colombia. American Journal of Epidemiology 175(10), 1045-1053.

Cervero, R. and Kang, C.D., 2011. Bus Rapid Transit impacts on land uses and land values in Seoul, Korea. Transport Policy 18, 102-116.

Donner, J., 2007. The use of mobile phones by microentrepreneurs in Kigali, Uganda: Changes to social and business networks. Information Technologies and International Development 3(2), 3-19.

Economist Intelligence Unit, 2010. Latin American Green City Index. Siemens AG, Munich. 
Embarq Brasil, 2011. Copa do Mundo de 2014 promove o transporte sustentável no Brasil [World cup 2014 promotes sustainable transportation in Brazil], http://www.ctsbrasil.org/node/291 [Accessed March 05, 2012].

FONADIN, 2010. Programa apoyo federal al transporte masivo-PROTRAM [Federal support program to massive transport-PROTRAM], http://cnec.org.mx/cnec/images/documentos/programa_de_apoyo_federal_al_transporte_masivo.pdf [Accessed March 05, 2012].

Gandy, M., 2005. Cyborg urbanization: Complexity and monstrosity in the contemporary city. International Journal of Urban and Regional Research 29(1), 26-49.

Gareth Lofthouse, Economist Intelligence Unit (Eds.), 2004. Megacity challenges - A stakeholder perspective. Siemens AG, Munich.

Geels, F. W., 2005. Processes and patterns in transitions and system innovations: Refining the coevolutionary multi-level perspective. Technological Forecasting \& Social Change 72, 681-696.

Geels, F. W., 2002. Technological transitions as evolutionary reconfiguration processes: a multi-level perspective and a case-study. Research Policy 31, 1257-1274.

Geels, F. W. , Schot, J., 2010. The dynamics of transitions: A socio-technical perspective, in: Grin, J., Rotmas, J., Schot, J., Transitions to sustainable development: New directions in the study of long term transformative change. Routledge, New York, pp. 9-101.

Greiner, M.A. and Franza, R.M. 2003. Barriers and bridges for successful environmental technology transfer. Journal of Technology Transfer 28, 167-177.

Grin, J., Rotmans, J., Schot, J., 2010. From persistent problems to system innovations and transitions, in: Grin, J.; Rotmas, J. and Schot, J., Transitions to sustainable development: new directions in the study of long term transformative change. Routledge, New York, pp. 1-8.

Heller, T. 2002. Greening of Industry Network sets sights on industrial transformation. Group examines future of corporate environmental initiatives. International Environmental Systems Update (IESU) 9(7).

Hensher, D.A., Golob, T.F., 2008. Bus rapid transit systems: a comparative assessment. Transportation 35, 501-518.

Hidalgo, D., Gutierrez, L., Lindau, L.A., 2010. Status of the BRT industry. Presentation at the BRTALC Center of Excellence meeting, Washington DC, January 25, 2010.

http://www.slideshare.net/EMBARQNetwork/status-of-the-brt-industry-6937307 [Accessed August 20, 2012].

Hidalgo, D., Lleras, G. and Hernández, E., 2012. Methodology for calculating passenger capacity in bus rapid transit systems: Application to the Transmilenio system in Bogotá, Colombia. Research in Transportation Economics, http://dx.doi.org/10.1016/j.retrec.2012.06.006.

Hillman, K., Nilsson, M., Rickne, A., Magnusson, T., 2011. Fostering sustainable technologies: a framework for analyzing the governance of innovation systems. Science and Public Policy 38(5), 403415. 
Hodson, M., Marvin, S., 2010. Can cities shape socio-technological transitions and how would we know if they were? Research Policy 39, 477-485.

Hodson, M., Marvin, S., 2009. Cities mediating technological transitions: understanding visions, intermediation and consequences. Technology Analysis \& Strategic Management 21(4), 515-534.

ITDP, 2011. Recapturing global leadership in Bus Rapid Transit. A survey of selected U.S. cities. ITDP, New York.

ITDP, 2007. Bus Rapid Transit planning guide. ITDP, New York.

Jaffe, A.B., Newell, R.G., Stavins, R.N., 2005. A tale of two market failures: Technology and environmental policy. Ecological Economics 54, 164-174.

Katz, B., Altman, A., 2007. An urban age in a suburban nation?, in: Burdett, R., Sudjic, D. (Eds.), The endless city. Phaidon Press Ltd., London, pp. 96-103.

Konrad, K., Truffer, B., Voß, J-P., 2008. Multi-regime dynamics in the analysis of sectoral transformation potentials: evidence from German utility sectors. Journal of Cleaner Production 16, 1190-1202.

Lámbarry Vilchis, F., Rivas Tovar, L.A. and Peña Cruz, M.P., 2011. Planeación de los sistemas BRT y consensos entre transportistas y autoridades de gobierno durante su implementación: el caso de Metrobús y Mexibús [Planning of BRT systems and consensus between transport contractors and government's authorities during their implementation: the case of Metrobús and Mexibús].

Administración y Desarrollo 39(54), 133-150.

Lin, Z. and Wu, J., 2007. Summary of the application effect of Bus Rapid Transit at Beijing southcentre corridor of China. J Transpn Sys Eng \& IT 7(4), 137-142.

Lindau, L.A. et al., 2008. Alternative financing for Bus Rapid Transit (BRT): The case of Porto Alegre, Brazil. Research in Transportation Economics 22, 54-60.

Low, N., Gleeson, B., Rush, E., 2003. Making believe: Institutional and discursive barriers to sustainable transport in two Australian cities. International Planning Studies 8(2), 93-114.

McFarlane, C., 2010. The comparative city: knowledge, learning, urbanism. International Journal of Urban and Regional Research 34(4), 725-742.

McFarlane, C., 2006. Crossing borders: development, learning and the North-South divide. Third World Quarterly 27(8), 1413-1437.

Mejía-Dugand, S., Hjelm, O., Baas, L.W., 2011a. Improving energy and material flows: a contribution to sustainability in megacities. World Renewable Energy Congress,

http://dx.doi.org/10.3384/ecp110573169 [Accessed March 05, 2012].

Mejía-Dugand, S., Hjelm, O., Baas, L.W., 2011b. Megacities: turning ten million faces at Swedish environmental technology. The R\&D management conference, http://urn.kb.se/resolve?urn=urn:nbn:se:liu:diva-67601 [Accessed March 05, 2012]. 
Mondal, M.A.H., Kamp, L.M., Pachova, N.I., 2010. Drivers, barriers, and strategies for implementation of renewable energy technologies in rural areas in Bangladesh - An innovation systems analysis. Energy Policy 38, 4626-4634.

Nugoro, S.B., Fujiwara, A. and Zhang, J., 2010. The influence of BRT on the ambient PM10 concentration at roadside sites of Trans Jakarta Corridors. Procedia Environmental Sciences 2, 914924.

Peñalosa, E., 2011. Politics, power, cities. Public lecture hosted by LSE Cities, http://lsecities.net/media/objects/events/2011-01-11-politics-power-cities [Accessed August 15, 2012].

Pereira, R., 2003. Corredores sem degradação [Corridors without degradation]. UrbS Magazine 32, October/November 2003.

Perrels, A., 2008. Wavering between radical and realistic sustainable consumption policies: in search for the best feasible trajectories. Journal of Cleaner Production 16, 1203-1217.

Pinder, D., 2002. In defence of utopian urbanism: imagining cities after the 'end of utopia'. Geografiska Annaler 84 B (3-4), 229-241.

Ponnaluri, R.V., 2011. Sustainable Bus Rapid Transit initiatives in India: The role of decisive leadership and strong institutions. Transport Policy 18, 269-275.

Portafolio, 2011. Bogotá, ¿¿cuál es el plan? [Bogotá, what is the plan?], http://www.portafolio.co/opinion/bogota-cual-es-el-plan [Accessed February 23 2012].

Portugali, J., 2000. Self-organization and the city. Springer-Verlag, Berlin.

Robinson, J., 2011. Cities in a world of cities: the comparative gesture. International Journal of Urban and Regional Research 35(1), 1-23.

Rogers, E.M., 2003. Diffusion of innovations, $5^{\text {th }}$ edition. Free Press, New York.

Rogers, E.M., Medina, U.E., Rivera, M.A., Wiley, C.J., 2005. Complex adaptive systems and the diffusion of innovations. The Innovation Journal: The Public Sector Innovation Journal 10(3), article 29.

Sargisson, L., 2011. Architecture and Utopia: three contrasting case studies: Dubai, New Urbanism and Cohousing. Abstract sent to the symposium Green futures: From utopian grand schemes to micropractices, http://urbantactics.files.wordpress.com/2011/09/green-futures-final-program.doc [Accessed September 12, 2012].

Satterfield, M.C. et al., 2009. Overcoming nontechnical barriers to the implementation of sustainable solutions in industry. Environmental Science \& Technology 43(12), 4221-4226.

Smith, A., Stirling, A., Berkhout, F., 2005. The governance of sustainable socio-technical transitions. Research Policy 34, 1491-1510.

Steenberghen, T., López, E., 2008. Overcoming barriers to the implementation of alternative fuels for road transport in Europe. Journal of Cleaner Production 16, 577-590. 
Toufexis, A., 1989. Planet of the year: overpopulation too many mouths. TIME magazine, http://www.time.com/time/magazine/article/0,9171,956645,00.html. [Accessed 08 September, 2011].

WBGU, 2011. World in transition - A social contract for sustainability, http://www.wbgu.de/en/flagship-reports/fr-2011-a-social-contract/ [Accessed February 27, 2012].

WBCSD, 2009. Mobility for development, http://www.wbcsd.org/Pages/EDocument/EDocumentDetails.aspx?ID=45. [Accessed 15 November, 2011].

Wiedmann, K-P. et al., 2011. Adoption barriers to sustainable solutions in the automotive sector. Journal of Business Research 64, 1201-1206.

Wöhrnschimmel, H. et al., 2008. The impact of a Bus Rapid Transit system on commuter's exposure to Benzene, CO, PM2.5 and PM10 in Mexico City. Atmospheric Environment 42, 8194-8203. 